\title{
Attraction to conspecifes in Rhinella icterica and $R$. ornata tadpoles (Anura: Bufonidae)
}

\author{
Alexandre Polettini Neto ${ }^{I}$ \& Jaime Bertoluci ${ }^{1}$ *it \\ ${ }^{1}$ Universidade de São Paulo, Escola Superior de Agricultura Luiz de Queiroz, Departamento de Ciências \\ Biológicas, Av. Pádua Dias, 11, 13418-900, Piracicaba, SP, Brasil \\ *Corresponding author: Jaime Bertoluci,e-mail: jaime.bertoluci@usp.br
}

POLETTINI NETO, A., BERTOLUCI, J. Attraction to conspecifes in Rhinella icterica and R. ornata tadpoles (Anura: Bufonidae). Biota Neotropica 21(1): e20201095. https://doi.org/10.1590/1676-0611-BN-2020-1095

\begin{abstract}
Tadpoles are able to perceive and discriminate signals from environment and they may use this ability in behaviors and ecological processes. Recognition mechanisms may be involved in schooling by means of attraction among individuals, characterizing a social process. By means of laboratory experiments the present study investigated the presence or absence of attraction to conspecifics in tadpoles of Rhinella icterica and R. ornata, two sympatric species from the Atlantic Forest of southeastern Brazil. We collected eggs of these two species in the field and reared them in laboratory according to two different methods (isolated or in groups of siblings). Tadpoles were submitted to experiments of choice between conspecifics, heterospecifics, and an empty compartment. Rhinella icterica tadpoles preferred to associate with conspecifics rather than $R$. ornata tadpoles, and we verified this is an innate behavior. Rhinella ornata tadpoles failed to discriminate between conspecifics and $R$. icterica tadpoles. When submitted to choice between a group of tadpoles of the other species and an empty compartment, R. icterica tadpoles presented random distribution, while $R$. ornata tadpoles preferred to associate with heterospecifics. Our results indicate $R$. icterica tadpoles have preference to associate with conspecifics, while $R$. ornata tadpoles may school indiscriminately. This study contributes for a better understanding of larval anuran social behavior.
\end{abstract}

Keywords: anuran larvae; behavior; communication; sympatric species; Atlantic Forest; schooling; southeastern Brazil.

\section{Atração por coespecíficos em girinos de Rhinella icterica e $R$. ornata (Anura: Bufonidae)}

\begin{abstract}
Resumo: Os girinos são capazes de perceber e discriminar sinais do ambiente e podem usar essa capacidade em comportamentos e processos ecológicos. Mecanismos de reconhecimento podem estar envolvidos na agregação por meio da atração entre indivíduos, caracterizando um processo social. O presente estudo investigou, por meio de experimentos de laboratório, a presença ou ausência de atração por coespecíficos em girinos de Rhinella icterica e R. ornata, duas espécies simpátricas, da Mata Atlântica do sudeste do Brasil. Coletamos ovos dessas duas espécies no campo e os cultivamos em laboratório de acordo com dois métodos diferentes (isolados ou em grupo de irmãos). Os girinos foram submetidos a experimentos de escolha entre coespecíficos, heteroespecíficos e compartimento vazio. Girinos de Rhinella icterica preferiram associar-se a coespecíficos do que com girinos de $R$. ornata, e verificamos que este é um comportamento inato. Os girinos de Rhinella ornata não conseguiram discriminar entre coespecíficos e girinos de $R$. icterica. Quando submetidos à escolha entre um grupo de girinos da outra espécie e um compartimento vazio, os girinos de $R$. icterica apresentaram distribuição aleatória, enquanto os girinos de $R$. ornata preferiram associar-se a girinos heteroespecíficos. Nossos resultados indicam que girinos de $R$. icterica preferem associar-se a coespecíficos, enquanto girinos de $R$. ornata podem agregar-se indiscriminadamente. Este estudo contribui para uma melhor compreensão do comportamento social de larvas de anuros.
\end{abstract}

Palavras-chave: larvas de anuros; comportamento; comunicação, espécies simpátricas; Mata Atlântica; agregação, Sudeste do Brasil. 


\section{Introduction}

Recognition mechanisms (of relatives, conspecifics, mates, neighbours, rivals, prey or predators) are essential for survival, reproduction and social interactions between organisms (Sherman et al. 1997). Among anuran larvae, chemical communication plays a key role in several behaviors, such as communication between a female and its offspring (Kam \& Yang 2002; Stynoski \& Noble 2012), detection of alarm cues in prey-predator contexts (Hews 1988; Hokit \& Blaustein 1995; Summey \& Mathis 1998; Kiesecker et al. 1996, 1999), intraspecific competition (Glennemeier \& Denver 2002), microhabitat and food discrimination (Pfening 1990; Gamboa et al. 1991; Hall et al.1995; Sontag et al. 2006), and recognition of predators (Petranka et al. 1987; Lawler 1989; Kiesecker et al. 1996), conspecifics (Leu et al. 2013; Chapman et al. 2015; Raven et al. 2017), and kin (Blaustein \& O'Hara, 1982; Waldman 1986; Rajput et al. 2014; Pizzatto et al. 2016; Raven et al. 2017).

In tadpoles, recognition abilities based on chemical signals are developed during the embryonic phase or shortly after hatching (Waldman 1981, 1882; Blaustein \& O'Hara 1982; Hepper \& Waldman 1992) and may persist after metamorphosis (Blaustein et al.1984; Waldman 1989; Graves et al. 1993; Flowers and Graves 1997). Due to vulnerability to predators at this stage, some species have developed strategies such as metamorphosis synchronization and aggregation (Pulliam \& Caraco 1984; Hews, 1988). In this case, spatial aggregation may be based primarily on conspecific attraction rather than mediated by environmental factors (Graves et al. 1993). Non-social groups are formed in response to attractive environmental characteristics (e.g., feeding microhabitats and temperature gradients), while social groups are formed from attraction between individuals (Wassersug 1973; Hoff et al.1999). Thus, communication characterizes social behavior (Townsend et al. 2003).

In this context, the present study sought to analyse, through laboratory experiments, the presence or absence of attraction to conspecifics in tadpoles of two congeneric species (Rhinella icterica and $R$. ornata) that occur in sympatry and show a wide distribution in the Atlantic Forest of southeastern Brazil. These species are able to school during larval phase (Eterovick 2000; Simon 2010).

These species belong to the family Bufonidae, which is composed by 53 genera and 629 species (Frost 2020). In the genus Rhinella Fitzinger, 1826, there are 92 species distributed from southern United States to southern South America (Frost 2019). Rhinella icterica is included in Rhinella marina Group (Maciel et al. 2010), while $R$. ornata belongs to the Rhinella crucifer Group (Baldissera Jr. et al. 2004).

Reproductive isolation between $R$. icterica and $R$. ornata may not be effective, due to sympatric occurrence, overlapping of reproductive sites and seasons of reproduction and close relationship between them (Bertoluci 1998; Bertoluci \& Rodrigues 2002; Abrunhosa et al. 2006), enabling interspecific amplexes and the occurrence of non-viable hybrids (Haddad \& Cardoso 1990). The same habitat is shared by these two tadpole species of different kinship degrees and development stages, thus, an intra and interspecific communication system would has an important adaptive value for them.

Until now, only one study has sought to analyze attraction to conspecifcs in Brazilian tadpoles (Rhinella marina; Raven et al. 2017), but this was done with invasive populations in the Australian territory. Thus, the present study contributes to an important knowledge gap of Brazilian tadpoles' behavior.
Therefore, we aimed to answer, for each species, the following questions: (1) do tadpoles prefer to associate with conspecifics rather than heterospecifics? (2) Does prior social experience (isolation or group rearing) influence recognition mechanism?

\section{Material and Methods}

\section{Egg collection}

We collected eggs from two spawns of $R$. icterica and two spawns of $R$. ornata, between 24 July and 14 August 2017, encompassing the reproductive season of the target species (Bertoluci \& Rodrigues 2002). We identified spawns based on size and arrangement of eggs within the gelatinous strings: smaller eggs arranged in a single string in Rhinella ornata, larger eggs arranged in a double string in R. icterica (Simon 2010). We transported eggs to laboratory in plastic pots containing local water.

We collected eggs in the Estação Biológica de Boracéia (EBB), a well-preserved Atlantic Forest reserve of Serra do Mar in São Paulo state $\left(23^{\circ} 38^{\prime} \mathrm{S}, 45^{\circ} 52^{\prime} \mathrm{W}\right)$. EBB has an area of 16,450 ha and is located at altitudes around $900 \mathrm{~m}$ a.s.l. The area is covered by Dense Ombrophylous Forest, where the presence of palm trees, ferns and giant bamboos is common (Travassos \& Camargo 1958; Heyer et al.1990; Bertoluci \& Rodrigues 2002). Rainy season runs from September to March, and temperature can reach $24^{\circ} \mathrm{C}$ in the hottest months (September to March) and $5^{\circ} \mathrm{C}$ in the colder months (April to August) (Bertoluci \& Rodrigues 2002).

\section{Rearing methods}

We conditioned eggs of two spawns (spawn A and spawn B) of each species, in laboratory, according to two different methods. They were separated from the rest of the embryos in the spawn between stages 16 and 18 (Gosner 1960).

At the $1^{\text {st }}$ rearing method (group of siblings), we placed 300 eggs of each spawn of $R$. icterica in two different $50 \mathrm{~L}$ opaque containers and we did the same with eggs of $R$. ornata. At the $2^{\text {nd }}$ method (isolation rearing), we placed 50 eggs from spawn $\mathrm{A}$, of each species, each egg in a $0.5 \mathrm{~L}$ opaque container, in 50 different containers.

We maintained eggs and tadpoles at room temperature and natural photoperiod. Tadpoles were fed once daily with ornamental fish food in large quantities so that food was always available. Aeration pumps for aquariums provided oxygenation. We changed the water in each container twice a week to keep the environment clean. After the metamorphosis, we released juveniles at the egg collection sites.

\section{Experiments}

Tests were carried out in four plastic containers $(100 \times 15 \times 10 \mathrm{~cm})$, filled with spring water (Fig. 1). At each end of a container we adapted a plastic net with a mesh of $0.5 \mathrm{~mm}$, delimiting the stimulus groups areas (20 tadpoles in each group). The central part of each container was marked with a permanent pen, dividing it into three equal-sized compartments.

We performed the tests between 25 August and 27 September 2017, during daytime, between 08:00 a.m. and 6:00 p.m. Tested tadpoles were between stages 25 and 38 (Gosner 1960).

We placed test tadpoles in the center of each container and submitted to choice tests between two groups (Fig. 1) (as in Blaustein \& O'Hara 1982; Cornell et al. 1989; Leu et al. 2013; Rajput et al. 2014; Pizzatto et 


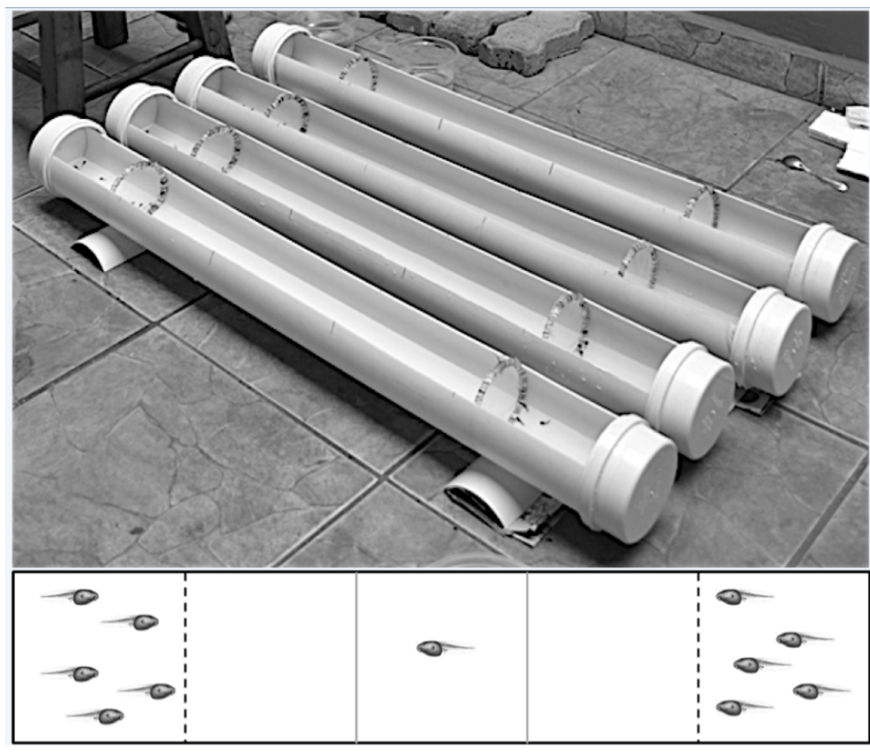

Figure 1. Test arena. Stimulus groups (20 tadpoles in each group) are represented in the right and left extremities, and test tadpole is represented in central area. Dashed line represents a net, which delimits stimulus groups areas, but allows chemical and visual stimuli flow to central region. Vertical gray lines represent demarcation of areas close to each stimulus group. Each division is $20 \mathrm{~cm}$ long, totalling $100 \mathrm{~cm}$ of arena total length.

al. 2016). We filmed the experiments (Kodak z990 camera), so researcher presence did not influence tadpole behavior. After 10 minutes of test tadpole acclimation, we filmed each experiment for 29 minutes (1740 s), and then we measured the time each tadpole remained in the compartment next to each stimulus group. Each tadpole was tested only once and, after each test, containers were cleaned and the water changed. At each test we turned the containers to $90^{\circ}$ and inverted the side of each stimulus group. Each experiment was replicated 32 times. Four replicates were filmed at a time. All procedures were repeated for both species.

We organized the experiments as follows:

Control: all tadpoles (test tadpoles and stimulus groups) from the same spawn and reared together in one container. With this experiment we were able to analyse if there were errors in experimental design. The expected was that test tadpoles had no preference for association with one of the two groups.

Experiment 1: test tadpole from spawn B reared according to $1^{\text {st }}$ rearing method. Stimulus group 1 formed by tadpoles of spawn A (conspecifics tadpoles, but not siblings of test tadpole). Stimulus group 2 formed by tadpoles of the other studied species (heterospecifics). With this, we sought to analyse if there was preference of association with conspecifics by the species tested.

Experiment 2: test tadpoles from spawn A reared according to the $2^{\text {nd }}$ rearing method (in isolation). Stimulus group 1 formed by tadpoles of spawn B, reared according to $1^{\text {st }}$ rearing method. Stimulus group 2 formed by heterospecific tadpoles. With this, we sought to analyse if the rearing method in total isolation would influence association choice by tested tadpoles with one of the stimulus groups.

Experiment 3: test tadpole from spawn A, reared according to the $1^{\text {st }}$ rearing method. Stimulus group 1 formed by heterospecific tadpoles. Stimulus group 2 empty (tadpoles absence). With this experiment we sought to analyse sociability of tested tadpoles (preference for grouping or isolation), and attraction or repulsion by tested tadpoles to heterospecific tadpoles.

\section{Data analyses}

We performed statistical analyses with $\mathrm{R}$ platform ( $\mathrm{R}$ Core Team 2017). We consider level of significance $\alpha=0.05$. Tests were two-tailed. Confidence level used was $95 \%$. For each experiment, data considered in the statistical tests were the differences between the time spent by the test tadpole in the compartments located near stimulus groups 1 and 2 (T1-T2). We verified if data of each experiment corresponded to normal distribution by Shapiro-Wilk test $\left(\mathrm{H}_{\mathrm{o}}=\right.$ data correspond to normal distribution). To data that reached the normal distribution we applied paired t-test, due to dependence of samples, since two measurements were made for the same individual in each experiment (paired data). Nonparametric alternative to t-paired test is Wilcoxon signed-rank test, which was applied to data that did not reach normal distribution. With the tests, we were able to analyse whether the difference between time spent by test tadpoles near each of two stimulus groups was statistically significant. The null hypothesis was that mean (or median) of the differences is null $\left(\mathrm{H}_{0}: \Delta=0\right)$, while the alternative hypothesis was that mean (or median) of the differences is not null $(\mathrm{H} 1: \Delta \neq 0)$. When the null hypothesis was rejected, we used binomial test to verify whether the number of tadpoles that spent the most time near a stimulus group was statistically significant in relation to total number of replicates.

Data obtained in experiments Control, 1 and 3 with Rhinella icterica tadpoles and in experiments Control, 1 and 3 with $R$. ornata tadpoles corresponded to normal distribution (Shapiro-Wilk test; Table 2 and 3); in these cases, we used paired t-test to detect differences between time spent by test tadpoles next to each stimulus group. However, in experiments 2 with $R$. icterica data did not correspond to normal distribution (ShapiroWilk test; Tables 1 and 2), so we used Wilcoxon test.

\section{Results}

The differences between time spent by test tadpoles close to each stimulus group, as well as the mean of the differences (value used in the Paired t-test) and pseudomedian differences (value used in the Wilcoxon test), when negative, indicate a longer permanence time of test tadpoles close to stimulus group 2, whereas, when positive, they indicate a longer permanence time of the tadpoles test near to stimulus group 1 (Tables 2 and 3, Figs. 2 and 3). In general, data obtained with experiments varied more for R. ornata than for R. icterica (Figs. 2 and 3).

In experiments Control and 3 with $R$. icterica and in experiments Control and 1 with $R$. ornata, the mean differences did not differ statistically from hypothetical mean obtained by paired t-test (Tables 2 and 3 ). Therefore, for these experiments, we did not reject the null hypothesis and concluded that there was no statistically significant difference between time spent by tadpoles next to each stimulus group $\left(\mathrm{H}_{0}: \Delta=0\right)$.

In experiment 1 with $R$. icterica and in experiment 3 with $R$. ornata, the mean differences differed statistically from hypothetical mean obtained by paired t-test (Tables 2 and 3). Similarly, in Experiment 2 with $R$. icterica, the pseudomedian differences differed statistically from the hypothetical median by Wilcoxon test (Tables 2 and 3). Therefore, for these experiments, we rejected the null hypothesis and concluded that there was a statistically significant difference between time spent by tadpoles next to each stimulus group ( $\mathrm{H} 1: \Delta \neq 0)$. In these experiments, we confirmed, with the binomial test, that the number of tadpoles that showed preference for group 1 was significant in relation to the total number of replicates (Tables 2 and 3). 
Polettini Neto, A. et al.

Table 1. Synthesis of experiments and control. In the first rearing method, tadpoles were reared with its siblings, and in the second method each tadpole was reared in isolation. The test tadpoles were submitted to choice between two stimulus groups of conspecifcs, heterospecifics or empty compartment.

\begin{tabular}{lccc}
\hline Experiment & Test tadpole & Stimulus Group 1 & Stimulus Group 2 \\
\hline Control & $1^{\text {st }}$ rearing method & Conspecifcs & Conspecifics \\
1 & $1^{\text {st }}$ rearing method & Conspecifcs & Heterospecifics \\
2 & $2^{\text {nd }}$ rearing method & Conspecifcs & Heterospecifics \\
3 & $1^{\text {st }}$ rearing method & Heterospecifics & Empty \\
\hline
\end{tabular}

Table 2. Statistical tests results for each experiment with Rhinella icterica tadpoles. When $\mathrm{P}<0,05$, there is statistically significant difference between time spent by tadpoles next to each stimulus group. $\mathrm{df}=$ degrees of freedom; $\mathrm{CI}=$ confidence interval.

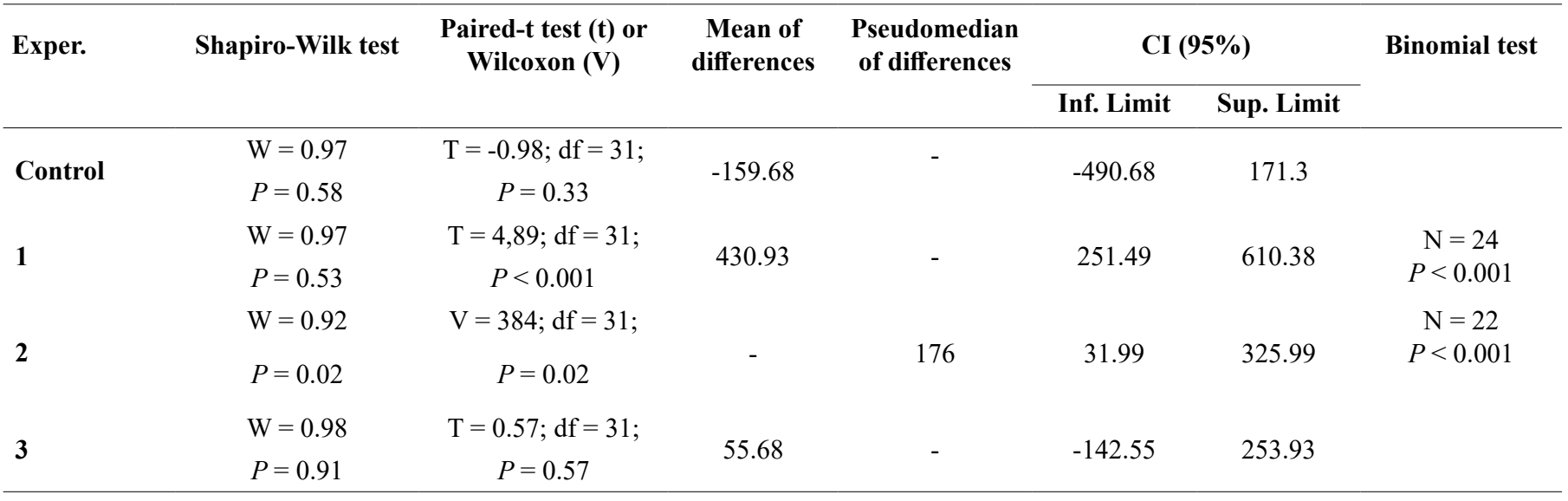

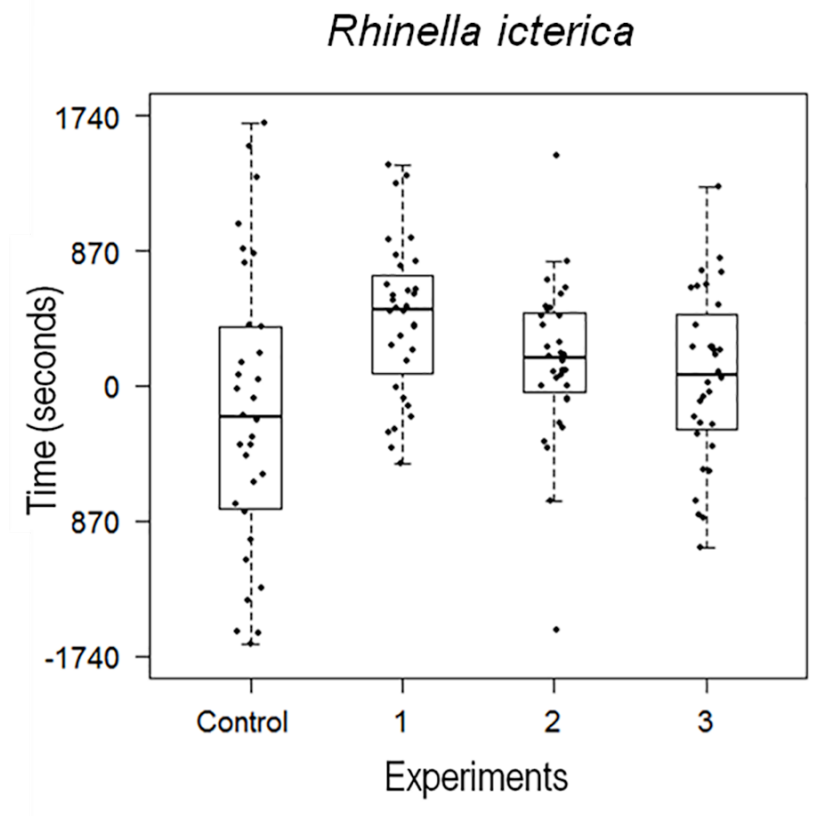

Figure 2. Boxplot of data resulting from the experiments with Rhinella icterica tadpoles. Each point represents the difference between time spent by tested tadpole, in each trial, close to stimulus groups 1 and 2.

Unfortunately, we made a mistake when choosing test tadpole in Experiment 2 for Rhinella ornata, and we realized in time to not use these data, but was not possible to repeat the experiment. Therefore, we were unable to determine whether isolation rearing would influence attraction to conspecifcs in tadpoles of $R$. ornata.

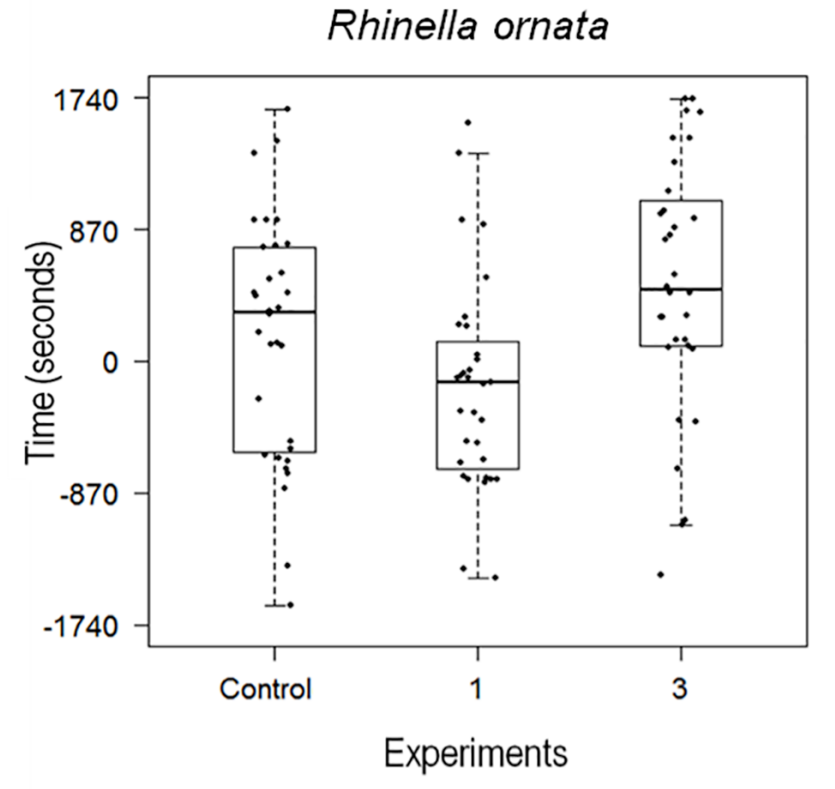

Figure 3. Boxplot of data resulting from the experiments with Rhinella ornata tadpoles. Each point represents the difference between time spent by tested tadpole, in each trial, close to stimulus groups 1 and 2.

\section{Discussion}

Rhinella icterica tadpoles demonstrated a strong attraction to conspecifics. This result suggests that these tadpoles possess the ability to discriminate between conspecifics and heterospecifics. We could conclude 
Table 3. Statistical tests results for each experiment with Rhinella ornata tadpoles. When $\mathrm{P}<0,05$ there is statistically significant difference between time spent by tadpoles next to each stimulus group. $\mathrm{df}=$ degrees of freedom; $\mathrm{CI}=$ confidence interval.

\begin{tabular}{|c|c|c|c|c|c|c|}
\hline Exper. & Shapiro-Wilk test & Paired-t test (t) & Mean of differences & \multicolumn{2}{|c|}{ CI $(95 \%)$} & Binomial test \\
\hline Control & $\begin{aligned} \mathrm{W} & =0.96 \\
P & =0.47\end{aligned}$ & $\begin{array}{c}\mathrm{T}=1.08 ; \mathrm{df}=31 ; \\
P=0.28\end{array}$ & 154.37 & -135.44 & 444.19 & - \\
\hline 1 & $\begin{array}{l}\mathrm{W}=0.94 \\
P=0.10\end{array}$ & $\begin{array}{c}\mathrm{T}=-1.41, \mathrm{df}=31 \\
P=0.16\end{array}$ & -174.12 & -425.26 & 77.01 & - \\
\hline
\end{tabular}

that this attraction behavior is innate, since tadpoles reared in isolation, from the embryonic stage, also demonstrated preference to associate with conspecific tadpoles. The preference to conspecifics is a result of attraction to conspecifics rather than repulsion to heterospecifics, because tadpoles of $R$. icterica have been randomly allocated when submitted to a choice between heterospecifics and an empty compartment.

Rhinella marina tadpoles, that belong to the same phylogenetic group as R. icterica (Rhinella marina Group; Maciel et al. 2010), when submitted to choice tests between a non-siblings group and an empty compartment, showed no attraction for conspecific when these were non-siblings (Raven et al. 2017). However, $R$. marina tadpoles diminish activity and avoid chemical cues of injured conspecifics, characterizing a recognition and discrimination process, but this does not lead to aggregation, which is formed in response to environmental factors such as light, temperature and habitat structural complexity (Hagman \& Shine 2008; Raven et al. 2017). There are different reactions of another bufonid tadpoles to injured conspecifics cues: Anaxyrus boreas also exhibit repulsion to these signals, but with increased activity (Hews \& Blaustein 1985), while Sclerophrys danielae answer to these cues aggregating (Spieler \& Linsenmair 1997).

Sontag et al. (2006) demonstrated that tadpoles of Anaxyrus americanus recognize conspecifics signals to find food sources and even to discriminate food quality. Similarly, tadpoles of $R$. marina have a stronger attraction to conspecific cues feeding than to cues directly from food (Raven et al. 2017).

Conspecific recognition mechanisms can be used in cannibalism context. Crossland \& Shine (2011) found that $R$. marina tadpoles are attracted by chemical cues from conspecific eggs and they eat them. This behavior is not a result of indiscriminate foraging, as these tadpoles rarely eat eggs of other species present in the same habitat (Crossland \& Shine 2010). This type of cannibalism can provide an important nutrition source for tadpoles and reduce future intraspecific competition (Crossland et al. 2011). In addition, by finding conspecific eggs, $R$. marina tadpoles can release chemicals that suppress the development of embryos (Crossland $\&$ Shine 2012, Clarke et al. 2015).

Crossland et al. (2011) have demonstrated that the substances involved in attraction process of $R$. marina tadpoles by conspecific eggs are toxins used in defence against predators, known as bufadienolids. Thus, it is possible that these substances are involved in attraction to conspecifics in tadpoles of $R$. icterica and other bufonids. These examples of behaviors based on attraction to conspecific cues in species genetically related to $R$. icterica suggest that attraction to conspecifics in this species may be related to similar behaviors. However, further studies are needed to verify if this attraction to conspecific is related with some recognition mechanism.

We found a notable difference between $R$. icterica and $R$. ornata tadpoles in relation to attraction to conspecifics. Rhinella ornata tadpoles did not prefer any of the groups, formed by either conspecifics or heterospecifics, indicating that attraction to conspecifics in this species may not occur. Rhinella ornata tadpoles spent more time near heterospecifics than the empty compartment, which suggests that $R$. ornata tadpoles prefer to associate with tadpoles of another species than to be isolated.

Some species of tadpoles exhibit schooling behavior (e.g., Beiswenger 1975, 1977; Wassersug et al. 1981; Eterovick 2000; Heursel \& Haddad 2002). Functions and benefits attributed to this behavior include predation rate decrease - due to predator confusion and aposematism enhancement-, foraging rate increase, and greater efficiency in thermoregulation (Watt et al.1997; Hoff et al. 1999; Eterovick 2000; Hero et al. 2001). However, when resources are limited, some costs of group formation may be evident, such as increasing competition, cannibalism and predation, as well as increasing disease and inbreeding susceptibility (Hamilton and May 1977; Bateson 1983; Shykoff \& Schmid-Hempel 1991; Pfening et al.1993; Goater 1994). Spatial attraction of tadpoles of $R$. ornata by tadpoles groups of $R$. icterica, as well as the non-repulsion of tadpoles of $R$. icterica to tadpoles groups of $R$. ornata tadpole, suggests that spatial interaction between these tadpoles in the natural environment does not involve large competition costs.

Some authors have attempted to explain the absence of discrimination among siblings by tadpoles under laboratory conditions as a consequence of lack of stimuli to reproduce the aggregation behavior (Blaustein \& Waldman 1992). The aggregation formation, with relatives or not, may be dependent on the balance between the costs and benefits of this behavior (Hamilton 1964). Both, recognition processes and aggregation can vary within the same species depending on some factors, such as presence and density of predators (Wrona \& Dixon 1991; Fitzgeral 1992; Watt et al. 1997) differences in tadpole diet (Gamboa et al. 1991; Pfenning 1990), development stage (Rautio et al. 1991; Blaustein \& Waldman 1992; Nicieza 1999), and resource distribution and temperature variation (Hokit \& Blaustein 1997). Lithobates sylvaticus tadpoles, for example, demonstrated kin recognition and attraction in laboratory experiments, but in natural environments they demonstrated both attraction and repulsion to kin in different ponds (Waldman 1984; Halverson et al. 2006). We were not able to consider the variable stage of development in our study, because of the rapid development and the great variation of development of tadpoles from the same spawn. This research opens a pathway for 
Polettini Neto, A. et al.

further studies analyse each variable that may be related to attraction to conspecifics in tadpoles of these two bufonids.

In this study, when opting for laboratory tests, we sought to avoid much of these variables, which could influence the results. Thus, our results suggest that attraction to conspecific may be a important factor for aggregation or association with other tadpoles in R. icterica, while tadpoles of $R$. ornata may aggregate indiscriminately or due to other variables than attraction to conspecifics. The behavior differences between two ecologically and genetically closely related species indicate that there may be no generalizations in anuran larvae behavior.

\section{Acknowledgements}

We thank CAPES for a grant to APN, ICMBio for collection and rearing permits (number 55886-3), MZUSP for the permission to access the study site, Denise Rossa Feres, Alexandre Percequillo, Fernando Rodrigues da Silva and Karl Mokroos for criticize parts of this work, and several colleagues that have helped in the fieldwork, including Denise M. Petroni, Gerson O. Romão, and Larissa C. Pedrozo. JB was a researcher of CNPq during this project (process number 309017/2016-5).

\section{Author Contributions}

Alexandre Polettini Neto. Substantial contribution in the concept and design of the study; Contribution to data collection; Contribution to data analysis and interpretation; Contribution to manuscript preparation; Contribution to critical revision, adding intelectual content.

Jaime Bertoluci. Substantial contribution in the concept and design of the study; Contribution to data analysis and interpretation; Contribution to manuscript preparation; Contribution to critical revision, adding intelectual content.

\section{Conflicts of interest}

The authors declare that they have no conflict of interest related to the publication of this manuscript.

\section{References}

ABRUNHOSA, P.A., WOGEL, H. \& POMBAL, J.P. 2006. Anuran temporal occupancy in a temporary pond from the Atlantic rain forest, south-eastern Brazil. Herpetol. J. 16(2):115-122.

BALDISSERAJR, F.E.A., CARAMASCHI, U \& HADDAD, C.F.B. 2004. Review of the Bufo crucifer species group, with descriptions of two new related species (Amphibia, Anura, Bufonidae). Arq. do Mus. Nac. RJ 1:255-282.

BEISWENGER, R.E. 1977. Diel patterns of aggregative behavior in tadpoles of Bufo americanus, in relation to light and temperature. Ecology 58(1):98-108.

BEISWENGER, R.E. 1975. Structure and function in aggregations of tadpoles of the American Toad, Bufo americanus. Herpetologica 31(2):222-233.

BERTOLUCI, J. 1998. Annual patterns of breeding activity in Atlantic Rainforest anurans. J. Herpetol. 32(4):607-611.

BERTOLUCI, J. \& RODRIGUES, M.T. 2002. Seasonal patterns of breeding activity of Atlantic Rainforest anurans at Boracéia, Southeastern Brazil. Amphib. Reptil. 23(2):161-167.

BLAUSTEIN, A.R. \& WALDMAN, B. 1992. Kin recognition in anuran amphibians. Anim. Behav. 44:207-221.

BLAUSTEIN, A.R. \& O'HARA, R.K. 1982. Kin recognition in Rana cascadae tadpoles: maternal and paternal effects. Anim. Behav. 30(4):1151-1157.
BLAUSTEIN, A.R. \& O'HARA, R.K. 1981. Genetic control for sibling recognition? Nature 290(5803):246-248.

BLAUSTEIN, A.R., O'HARA, R.K. \& OLSON, D.H. 1984. Kin preference behaviour is present after metamorphosis in Rana cascadae frogs. Anim. Behav. 32(2):445-450.

CHAPMAN, T.L., HOLCOMB, M.P., SPIVEY, K.L., SEHR, E.K. \& GALL, B.G. 2015. A test of local enhancement in amphibians. Ethology 121(3):308-314.

CLARKE, G.S., CROSSLAND, M.R., SHILTON, C. \& SHINE, R. 2015. Chemical suppression of embryonic cane toads Rhinella marina by larval conspecifics. J. Appl. Ecol. 52(6):1547-1557.

CORNELL, T.J., BERVEN, K.A. \& GAMBOA, G.J. 1989. Kin recognition by tadpoles and froglets of the wood frog Rana sylvatica. Oecologia 78(3):312-316.

CROSSLAND, M.R. \& SHINE, R. 2012. Embryonic exposure to conspecific chemicals suppresses cane toad growth and survival. Biol. Lett. 8(2):226-229.

CROSSLAND, M.R., HEARNDEN, M.N., PIZZATTO, L., ALFORD, R.A. \& SHINE, R. 2011. Why be a cannibal? The benefits to cane toad, Rhinella marina $[=$ Bufo marinus], tadpoles of consuming conspecific eggs. Anim. Behav. 82(4):775-782.

CROSSLAND, M.R. \& SHINE, R. 2010. Vulnerability of an Australian anuran tadpole assemblage to the toxic eggs of the invasive cane toad (Bufo marinus). Austral Ecol. 35(2):197-203.

CROSSLAND, M.R. \& SHINE, R. 2011. Cues for cannibalism: Cane toad tadpoles use chemical signals to locate and consume conspecific eggs. Oikos 120(3):327-332.

D'HEURSEL, A. \& HADDAD, C.F.B. 2002. Schooling and swimming behaviors of Hyla semilineata tadpoles (Anura, Hylidae). Iheringia, Série Zool. 92(1):99-104.

ETEROVICK, P.C. 2000. Effects of aggregation on feeding of Bufo crucifer tadpoles (Anura, Bufonidae). Copeia 2000(1):210-215.

FITZGERALD, G.J. \& MORRISSETTE, J. 1992. Kin recognition and choice of shoal mates by threespine sticklebacks. Ethol. Ecol. Evol. 4(3):273-283.

FLOWERS, M.A. \& GRAVES, B.M. 1997. Juvenile toads avoid chemical cues from snake predators. Anim. Behav. 53(3):641-646.

FROST, D. R. 2020. Amphibian species of the world: an online reference. Version 6.1. Eletronic database accessible at http://research.amnh.org/herpetology/ amphibia/index.html. American Museum of Natural History, New York, USA. doi.org/10.5531/db.vz.0001

GAMBOA, G.J., BERVEN, K.A., SCHEMIDT, R.A., FISHWILD, T.G. \& JANKENS, K.M. 1991. Kin recognition by larval wood frogs (Rana sylvatica): effects of diet and prior exposure to conspecifics. Oecologia 86(3):319-324.

GLENNEMEIER, K.A. \& DENVER, R.J. 2002. Role for corticoids in mediating the response of Rana pipiens tadpoles to intraspecific competition. J. Exp. Zool. 292(1):32-40.

GOATER, C.P. 1994. Growth and survival of postmetamorphic toads: Interactions among larval history, density, and parasitism. Ecology 75(8):2264-2274.

GOSNER, K. 1960. A simplified table for staging anuran embryos and larvae with notes on identification. Herpetologica 16(3):183-190.

GRAVES, B.M., SUMMERS, C.H. \& OLMSTEAD, K.L. 1993. Sensory mediation of aggregation among postmetamorphic Bufo cognatus. J. Herpetol. 27(3):315-319.

HADDAD, C.F.B. \& CARDOSO, A.J. 1990. Hibridação natural entre Bufo ictericus e Bufo crucifer (Amphibia: Anura). Rev. Bras. Biol. 50(3):739-744.

HAGMAN, M. \& SHINE, R. 2008. Understanding the toad code: Behavioural responses of cane toad (Chaunus marinus) larvae and metamorphs to chemical cues. Austral Ecol. 33(1):37-44.

HALL, J.A., LARSEN JR., J.H., DON, E.M. \& FITZNER, R.E. 1995. Discrimination of kin-and diet-based cues by larval spadefoot toads, Scaphiopus intermontanus (Anura: Pelobatidae), under laboratory conditions. J. Herpetol. 29(2):233-243.

HALVERSON, M.A., SKELLY, D.K. \& CACCONE, A. 2006. Kin distribution of amphibian larvae in the wild. Mol. Ecol. 15(4):1139-1145.

HAMILTON, W.D. \& MAY, R.M. 1977. Dispersal in stable habitats. Nature 269578. 
HAMILTON, W.D. 1964. The genetical evolution of social behaviour. I. J. Theor Biol. 7(1):1-16.

HEPPER, P.G. \& WALDMAN, B. 1992. Recognizing kin: ontogeny and classification. In Kin recognition (P.G. Hepper, ed.). Cambridge University Press, Cambridge, UK, p. 259-288.

HERO, J.M., MAGNUSSON, W.E., ROCHA, C.F.D. \& CATTERALL, C.P. 2001. Antipredator defenses influence the distribution of amphibian prey species in the central Amazon rain forest. Biotropica 33(1):131-141.

HEWS, D.K. 1988. Alarm response in larval western toads, Bufo boreas: release of larval chemicals by a natural predator and its effect on predator capture efficiency. Anim. Behav. 36(1):125-133.

HEWS, D.K. \& BLAUSTEIN, A.R. 1985. An investigation of the alarm response in Bufo boreas and Rana cascadae tadpoles. Behav. Neural Biol. 43(1):47-57.

HEYER, W.R., RAND, A.S., CRUZ, C.A.G., PEIXOTO, O.L. \& NELSON, C.E. 1990. Frogs of Boracéia. Arq. Zool. 31(4):231-410.

HOFF, K.S., BLAUSTEIN, A.R., MCDIARMID, R.W. \& ALTIG. R. 1999. Behavior: interactions and their consequences. In Tadpoles: the biology of anuran larvae (R.W. McDiarmid \& R. Altig, eds.). University of Chicago, Chicago, Illinois, USA, p. 215-239.

HOKIT, D.G. \& BLAUSTEIN, A.R. 1997. The effects of kinship on interactions between tadpoles of Rana cascadae. Ecology 78(6):1722-1735.

HOKIT, D.G. \& BLAUSTEIN, A.R. 1995. Predator avoidance and alarm-response behaviour in kin-discriminating tadpoles (Rana cascadae). Ethology 101(4):280-290.

KAM, Y.C. \& YANG, H.W. 2002. Female-offspring communication in a Taiwanese tree frog, Chirixalus eiffingeri (Anura: Rhacophoridae). Anim. Behav. 64(6):881-886.

KIESECKER, J.M., CHIVERS, D.P. \& BLAUSTEIN, A.R. 1996. The use of chemical cues in predator recognition by western toad tadpoles. Anim. Behav. 52(6):1237-1245.

KIESECKER, J.M., CHIVERS, D.P., MARCO, A., QUILCHANO, C., ANDERSON, M.T. \& BLAUSTEIN, A.R. 1999. Identification of a disturbance signal in larval red-legged frogs, Rana aurora. Anim. Behav. 57(6):1295-1300.

LAWLER, S.P. 1989. Behavioural responses to predators and predation risk in four species of larval anurans. Anim. Behav. 38(6):1039-1047.

LEU, S.T., WHITING, M.J. \& MAHONY, M.J. 2013. Making friends: social attraction in larval green and golden bell frogs, Litoria aurea. PLoS One 8(2): e56460.

MACIEL, N.M., COLLEVATTI, R.G., COLLI, G.R. \& SCHWARTZ, E.F. 2010 Late Miocene diversification and phylogenetic relationships of the huge toads in the Rhinella marina (Linnaeus, 1758) species group (Anura: Bufonidae). Mol. Phylogenet. Evol. 57(2):787-797.

NICIEZA, A.G. 1999. Context-dependent aggregation in common frog Rana temporaria tadpoles: Influence of developmental stage, predation risk and social environment. Funct. Ecol. 13(6):852-858.

PFENNIG, D.W. 1990. "Kin recognition" among spadefoot toad tadpoles: a sideeffect of habitat selection? Evolution 44(4):785-798.

PFENNIG, D.W., REEVE, H.K. \& SHERMAN, P.W. 1993. Kin recognition and cannibalism in spadefoot toad tadpoles. Anim. Behav. 46(1):87-94.

PETRANKA, J.W., KATS, L.B. \& SIH, A. 1987. Predator-prey interactions among fish and larval amphibians: use of chemical cues to detect predatory fish. Anim. Behav. 35(2):420-425.

PIZZATTO, L., STOCKWELL, M., CLULOW, S., CLULOW, J. \& MAHONY, M. 2016. How to form a group: Effects of heterospecifics, kinship and familiarity in the grouping preference of green and golden bell frog tadpoles. Herpetol. J. 26(2):157-164.

PULLIAM, H.R. \& CARACO, T. 1984. Living in groups: is there an optimal group size? In Behavioral Ecology: An evolutionary approach (J.R. Krebs \& N.R. Davis, eds). John Wiley \& Sons, Oxford, UK, p. 122-127.
R CORE TEAM. 2017. R: A language and environment for statistical computing. R foundation for statistical computing, Viena, Austria. https://www.R-project.org

RAJPUT, A.P., SAIDAPUR, S.K. \& SHANBHAG, B.A. 2014. Kin discrimination in tadpoles of Hylarana temporalis (Anura: Ranidae) and Sphaerotheca breviceps (Anura: Dicroglossidae): Influence of hydroperiod and social habits. Phyllomedusa 13(2):119-131.

RAUTIO, S.A., BURA, E.A., BERVEN, K.A. \& GAMBOA, G.J. 1991. Kin recognition in wood frog tadpoles (Rana sylvatica): factors affecting spatial proximity to siblings. Can. J. Zool. 69(10):2569-2571.

RAVEN, C., SHINE, R., GREENLEES, M., SCHAERF, T.M. \& WARD, A.J.W. 2017. The role of biotic and abiotic cues in stimulating aggregation by larval cane toads (Rhinella marina). Ethology 123(10):724-735.

SHERMAN, P.W., REEVE, H.K. \& PFENNIG, D.W. 1997. Recognition systems. In Behavioral ecology: an evolutionary approach, 4th ed. (J.R. Krebs \& N.B Davies, eds.). John Wiley \& Sons, Oxford, UK, p. 69-96.

SHYKOFF, J.A. \& SCHMID-HEMPEL, P. 1991. Genetic relatedness and eusociality: parasite-mediated selection on the genetic composition of groups. Behav. Ecol. Sociobiol. 28(5):371-376.

SIMON, M.N. 2010. Plasticidade fenotípica em relação à temperatura de larvas de Rhinella (Anura: Bufonidae) da caatinga e da floresta atlântica. Dissertação de mestrado. São Paulo: Instituto de biociências, Universidade de São Paulo.

SONTAG, C., WILSON, D.S. \& WILCOX, R.S. 2006. Social foraging in Bufo americanus tadpoles. Anim. Behav. 72(6):1451-1456.

SPIELER, M. \& LINSENMAIR, K.E. 1997. Choice of optimal oviposition sites by Hoplobatrachus occipitalis (Anura: Ranidae) in an unpredictable and patchy environment. Oecologia 109(2):184-199.

STYNOSKI, J.L. \& NOBLE, V.R. 2012. To beg or to freeze: Multimodal sensory integration directs behavior in a tadpole. Behav. Ecol. Sociobiol. 66(2):191-199.

SUMMEY, M.R. \& MATHIS, A. 1998. Alarm responses to chemical stimuli from damaged conspecifics by larval anurans: tests of three neotropical species. Herpetologica 54(3):402-408.

TOWNSEND, C.R., BEGON, M. \& HARPER, J.L. 2003. Fundamentos em Ecologia. Artmed, Porto Alegre, Rio Grande do Sul, Brazil.

TRAVASSOS, L. \& CAMARGO, H.F.A. 1958. A Estação Biológica de Boracéia. Arquivos de Zoologia 11:1-21.

WALDMAN, B. 1981. Sibling recognition in toad tadpoles: the role of experience. Z. Tierpsychol. 56(4):341-358.

WALDMAN, B. 1982. Sibling association among schooling toad tadpoles: field evidence and implications. Anim. Behav. 30(3).

WALDMAN, B. 1984. Kin recognition and sibling association among wood frog (Rana sylvatica) tadpoles. Behav. Ecol. Sociobiol. 14(3):171-180.

WALDMAN, B. 1986. Preference for unfamiliar siblings over familiar non-siblings in American toad (Bufo americanus) tadpoles. Anim. Behav. 34(1):48-53.

WALDMAN, B. 1989. Do anuran larvae retain kin recognition abilities following metamorphosis? Anim. Behav. 37(6):1055-1058.

WASSERSUG, R.J. 1973. Aspects of social behaviour in anuran larvae. In Evolutionary Biology of the Anurans (J. L. Vial, ed.) University of Missouri, Columbia, p. 273-297.

WASSERSUG, R.J., LUM, A.M. \& POTEL, M.J. 1981. An analysis of school structure for tadpoles (Anura: Amphibia). Behav. Ecol. Sociobiol. 9(1):15-22.

WATT, P.J., NOTTINGHAM, S.F. \& YOUNG, S. 1997. Toad tadpole aggregation behaviour: Evidence for a predator avoidance function. Anim. Behav. 54(4):865-872.

WRONA, F.J \& DIXON, R. 1991. Group size and predation risk: a field analysis of encounter and dilution effects. Am. Nat. 137(2):186-201.

Received: $27 / 07 / 2020$

Revised: $16 / 11 / 2020$

Accepted: 24/11/2020

Published online: 13/01/2021 